\title{
Universiteit
}

Leiden

The Netherlands

\section{Facets of the Cultural History of Mathematics} Geiges, $\mathrm{H}$.

\section{Citation}

Geiges, H. (1999). Facets of the Cultural History of Mathematics. Retrieved from https://hdl.handle.net/1887/5302

Version: $\quad$ Not Applicable (or Unknown)

License: $\quad$ Leiden University Non-exclusive license

Downloaded from: https://hdl.handle.net/1887/5302

Note: To cite this publication please use the final published version (if applicable). 
Facets of the Cultural History of Mathematics

Rede uitgesproken door

\section{Hansjörg Geiges}

bij de aanvaarding van het ambt van

hoogleraar in de Wiskunde

aan de Universiteit Leiden

gehouden op 12 november 1999 . 
Mijnheer de Rector Magnificus,

Excellentie,

\section{Zeer gewaardeerde toehoorders,}

The Roman architect Vitruvius is the source of the following story ${ }^{1}$ about the Socratic philosopher Aristippus. Being shipwrecked in Rhodes, he notices some geometric diagrams drawn on the beach, and says to his companions: "We can hope for the best, for I see the signs of men." The mathematical diagrams in the sand are regarded by Vitruvius as features that distinguish persons of culture and wisdom from their fellow citizens. While his companions later return to Athens, Aristippus decides to stay with his fellow philosophers in Rhodes. The message he sends home is that "children should be furnished with the sort of possessions [...] that can even survive a shipwreck in one piece." Still according to Vitruvius, this argument was taken further by other Athenians, who urged that people be well educated rather than relying on money. This resulted in the Athenian custom that grown children were required to support their elderly parents only if the parents had educated them properly.

You may well ask yourself how much of the attitude expressed in this story survives today. The educated public may retain a sense of awe towards mathematics and the mathematically skilled, and it may even concede the importance of applied mathematics in engineering and the sciences. But few would look back on the mathematical training they received at school as a source of culture, wisdom, or even education. What is much more disturbing, though, is that nowadays even many of those who would label themselves as 'humanist intellectuals' are, at best, blissfully unaware of most cultural contributions of mathematics or, at worst, positively hostile towards them.

In this lecture I want to discuss some cultural aspects of mathematics which I believe to be relevant for mathematicians and non-mathematicians alike. These aspects include the incorporation of mathematics in philosophical theories fundamental to our understanding of the world and the shaping of our society, and the general cultivating effects of mathematics. But this is as much pathos ${ }^{2}$ as I shall allow myself. Given the constraints of a lecture such as this, my aim can only be to present a few facets of the cultural history of mathematics, which I have chosen somewhat idiosyncratically.

The theme of my lecture is nicely summed up by what Norman Levitt wrote in a recent essay:

"Confronted with an obligation to deal seriously with mathematics, individuals often look for a way out. So, apparently, do cultures." 


\section{Greek Mathematics - Euclid's Elements}

The roots of the Western mathematical tradition lie in Greek antiquity, and here in particular in the Pythagorean ${ }^{3}$ school, in Plato's (ca. 429-348 B.C.) philosophy, and in Euclid's Elements ${ }^{4}$, written and compiled around 300 B.C. It must be regarded as an essential influence on Western philosophy and culture that one of Plato's central discussions of the educational rôle of mathematics can be found in a text on political organisation, The Republic. The famous educational programme set out there prescribes long immersion in mathematical study as an essential path towards the world of 'Forms' and 'Ideas', the region of intelligible entities that provides objects of knowledge, as opposed to the fragile opinions and beliefs about objects in the world of sensual perception. According to Plato, sure knowledge of this kind is indispensable both for the competent statesman and the philosopher aspiring to apprehend genuine being.

Geometry (as well as other parts of mathematics) developed to some degree independently in various cultures, amongst them the Babylonian, Egyptian, Arabic, Indian, and Chinese. This development was motivated largely by practical problems: in Egypt - land measurements for tax purposes after floodings of the Nile; in India - requirements by the Vedic religion for the building of altars to very exacting specifications.

It is not wholly justified to dismiss the mathematics in these cultures as a pure collection of recipes without reasoning or proofs ${ }^{5}$. But the distinctive contribution of the Greek mathematicians was the discovery and elaboration of the method of scientific enquiry which begins by positing plausible starting points and establishes conclusions from these first principles by formal deduction. Also, it was only in Greece that mathematics was awarded a special ontological status.

One of the sources for the special status of mathematics in Greek culture was the discovery by the Pythogarean school - one might almost say its founding principle - that harmonious chords are produced by the vibration of strings whose lengths are in simple whole-number ratios. This discovery had lasting influence on the belief in classical and later Christian culture that such harmonious ratios and relationships are intimations of harmonies built deep into the nature of things.

The special rôle of mathematics was further emphasised by Plato's philosophy, which accorded mathematical objects (for instance, the geometer's idealised mental triangle as opposed to its physical incarnation in the sand) the status of prime examples of the 'Forms' or 'Ideas' at the centre of his theories of existence and knowledge, that is, entities apprehended by human minds, but according to Plato persisting independently. The Platonic view of the world 
and the rôle played by mathematics may be summed up rather simplistically as follows: The truths of geometry are not learned through sensual experience, but are universal and timeless. Our capability to perceive such truths allows us to infer a realm of unchanging truths. This realm we have to regard as the source of our knowledge of the Good, that is, as the basis of our morality. These Platonic ideas form the core of the Western intellectual tradition and the basis of all Utopian thinking: To all genuine questions there should be one and only one true answer, and these true answers should in principle be knowable. In this simplistic form it is no doubt impossible to uphold this view, but I venture to say that interpreted appropriately, the Platonic views are still extremely potent today.

The special character of the Greek view towards mathematics found its expression in Euclid's Elements. This book has been regarded for more than two millennia as the paradigm of the acquisition and organisation of a body of knowledge. Starting from clear foundations expressed in terms of definitions and axioms, the book proceeds to prove proposition after proposition with inexorable logic, in the most economic manner, and with aesthetic perfection. (Needless to say, the rigorous modern mathematical point of view is slightly more critical, but cum grano salis this statement still holds.)

In the Platonic tradition, mathematical training, specifically in the rigorous technique of axiomatic geometry, was regarded as a necessary precursor to any significant philosophical speculation, and it is important to remember that the root meaning of 'mathematics' in Greek is 'learning' ( $\mu \propto \theta \eta \eta / \mathrm{l}$ ). The Elements' lasting influence on philosophical methodology is demonstrated by Spinoza's Ethics, written in the 1670s in the Euclidean style ${ }^{6}$, and geometry was of similar importance to the rationalist philosophers Descartes and Leibniz.

The Elements' influence on education is evident from their use, over many centuries, as the standard geometry textbook at schools and universities. Only from around the middle of the seventeenth century, the Elements were beginning to be replaced in continental Europe by modern textbooks. In England and the United States, the exclusive use of Euclid's book only declined as late as the $19^{\text {th }}$ century, largely as a result of the towering influence of the Mathematical Tripos ${ }^{7}$ at Cambridge University, which insisted upon purely Euclidean methods in its teaching. But even then, and well into the twentieth century, the primary purpose of geometry texts was to instil mental discipline, and not to teach technical skills for the solution of practical problems. To quote one particularly flowery dedication from the middle of the seventeenth century: "Go on, love and esteem this science, which I hold to be worthy of its renown; preeminent for its certainty, because it is a single structure; appealing to the finest intellects, because true; appropriate even to clerics, because good ....and thus conducive to praising and loving the one, 
the true, and the good, that is, the incorporeal God." ${ }^{\prime 8}$

Now, I am certainly not advocating a return to Euclid's Elements as a primary source for education in geometry, but I maintain that if we give up the teaching of geometry in the rigorous style of Euclid, we deprive gifted schoolchildren of an essential intellectual experience. ${ }^{9}$ I also believe that geometry, and mathematics in general, need to be taught in a cultural context. ${ }^{10}$ Let me give you a simple example. I mentioned earlier the philosophical significance to the Pythagorean school of harmonious, whole number ratios. Now it was actually that same school that discovered the irrationality of the square root of 2 or, put differently, the fact that the length of a side of a square and a diagonal of that square do not form a whole-number ratio. I remember being taught the beautiful and simple Pythagorean proof of this fact at school, and I would hope that it is still being taught in schools today. But the fascination of this proof also lies in its philosophical relevance, the unsettling impression it must have made on the Pythagorean school. ${ }^{11}$ In a similar vein, whenever I hear a journalist compare a political impossibility to 'the squaring of the circle', I wonder - if they don't use the phrase in the wrong context in the first place - how many of them are actually aware of the fact

(a) that what they are referring to is the question posed in Greek geometry whether it is possible to construct a square with the same area as a given circle, using ruler and compass alone;

(b) that ruler and compass constructions have a special methodological significance; and

(c) that the impossibility of this venture is a consequence of the transcendence of $\pi$, a fact proved as late as $1882 .{ }^{12}$

Incidentally, the literary career of the problem of circle squaring makes an intriguing subject in its own right. ${ }^{13}$ For instance, in the Paralipomena ${ }^{14}$ to Goethe's Faust - that is, the collection of notes, sketches, and drafts found in Goethe's literary estate - circle squaring figures as an exercise in geometry posed by Mephistopheles. But Goethe must have regarded this scene as a little too cheeky for the final edition. Circle squaring also appears in Thomas Mann's Magic Mountain, that deeply philosophical and pedagogical novel set in a sanatorium in the Swiss Alps at the beginning of our century. Thomas Mann, whose father-in-law was a professor of mathematics ${ }^{15}$, and whose wife had also studied mathematics, was well aware of the impossibility of circle squaring. He even plays on the technical reason for this impossibility, the transcendence of $\pi$, by referring to the 'transcendent goal' that the lawyer Paravant is trying to achieve by his futile attempts at circle squaring. In Mann's masterly ironic style, the absurdity of the whole enterprise is heightened by the fact that it appears alongside the drawing of piglets with your 
eyes closed as a major pursuit of the sanatorium's inmates. The occupation with mathematics is recommended by one of the doctors as the best remedy against 'cupidity' ${ }^{16}$ ('Kupidität'), which modern dictionaries tend to define only as 'greed for gain', but which also had, and here I believe is meant to have, slightly more carnal connotations. - So much for this literary digression. An important commentary on Euclid's Elements, interpreting them in the Platonic tradition, was provided in the fifth century A.D. by the Greek philosopher and geometer Proclus. According to Proclus, echoing ideas of Plato, the "cultivation of [mathematics] is worthy of earnest endeavour both for its own sake and for the sake of intellectual life". His discussion of the origin of the name 'mathematics', the science concerned with learning, Proclus concludes with the observation that this "name makes clear what sort of function this science performs. It arouses our innate knowledge, awakens our intellect, purges our understanding, brings to light the concepts that belong essentially to us, takes away the forgetfulness and ignorance that we have from birth, [and] sets us free from the bonds of unreason."17

Not long after Proclus wrote his commentary, the Roman Empire was overrun by the aptly named barbarians, whose barbarity manifested itself in their neglect of geometry. Most of Euclid's work and many other Greek mathematical texts were lost in the process. Western civilisation would not be what it is today - and there might not be any inaugural lectures for chairs in geometry - if many of the Greek mathematical treasures had not survived in Arabic translation, whence they returned to Europe in Latin translation in the twelfth century. The Greek text of the Elements - albeit in an edition written long after Euclid's death - had been preserved in Byzantium and came back to Europe during the Renaissance. One of the oldest Greek editions of the Elements was found in the $19^{\text {th }}$ century in the library of the Vatican. 


\section{Gothic Architecture}

Up to the eleventh century, geometry - and culture in general - were in a rather pitiful state. ${ }^{18}$ The light that began to illuminate the Dark Ages found its embodiment in the emerging Gothic architecture. For reasons of family history ${ }^{19}$ this is a subject dear to me, and you may excuse me if I seem to accord it more than its fair share of attention.

Arguably the most significant monography on the origins of Gothic architecture is Otto von Simson's The Gothic Cathedral. ${ }^{20}$ He writes that "with few exceptions the Gothic builders have been tight-lipped about the symbolic significance of their projects, but they are unaminous in paying tribute to geometry as the basis of their art."21

There are practical as well as aesthetic reasons for the use of geometry in Gothic architecture, but they cannot explain all secrets of Gothic architectural geometry. On the practical side, the use of geometric proportions allows to translate architectural drawings into the dimensions of the actual building without the use of standards of measurement. However, such standards were no longer uncommon in the $12^{\text {th }}$ and $13^{\text {th }}$ century. The aesthetic argument, on the other hand, fails to explain the use of geometric features in places that remain practically invisible.

The protocols of the conference of Italian, French and German architects in Milan in 1386, convened when the construction of Milan cathedral had run into difficulties, contain the basic creed: "ars sine scientia nihil est" - art is nothing without science; here 'art' stands for practical knowledge based on experience, 'science' for the rational foundation provided by geometry. The single most influential architectural school for the development of the Gothic style was that of the cathedral at Chartres in the second quarter of the $12^{\text {th }}$ century. Here the early medieval aesthetic of Augustine, which accorded geometry a special place among the liberal arts, merged with the rediscovered Greek geometry and astronomy to provide the philosophical foundations of the Gothic style on firmly Pythagorean-Platonic principles; and in many ways this school anticipated the Renaissance movement. ${ }^{23}$ By subjecting themselves to the principles of geometry, the Gothic builders meant to emulate the Creator, who had formed the universe according to those very principles. Thus the Gothic cathedrals have to be seen as models for the medieval universe, which imparts them with meaning beyond their beauty and their use as places of worship. ${ }^{24}$ 


\section{The $17^{\text {th }}$ Century - Aubrey's Brief Lives}

In spite of the unquestionable esteem in which mathematics was held by the medieval scholars, we must admit that they looked upon Greek mathematics in much the same way as on the Holy Scriptures. The texts provided philosophical and mathematical foundations for the artistic practice, but they were not regarded as parts of a living and growing body of knowledge. I shall not attempt to chart or explain the dramatic cultural changes that began with the Renaissance and the ensuing Scientific Revolution. Rather, I would like to focus my attention on an instructive and, I think, highly amusing facet of $17^{\text {th }}$ century life.

The Royal Society 'for the promoting of Physico-MathematicallExperimentall Learning' was set up in London in 1662. One of its founding members was John Aubrey, who has been described as "the greatest gossip columnist of the seventeenth century". He joined the ranks of distinguished scientists such as Hooke and Boyle, but the founding members also included poets like John Dryden or the architect Christopher Wren. In the regular Wednesday meetings of the Royal Society they could all be expected to take interest in discussions that often relied heavily on mathematical reasoning. Amongst Aubrey's sketches of the lives of his contemporaries are many devoted to mathematicians, whom he obviously regarded to be on a par with other exponents of the culture of his time, not only in terms of their cultural contributions, but also in terms of their suitability as subjects of gossip.

But there are many more entries in Aubrey's collection of portraits that make it quite plain that mathematics was regarded as something of an arbiter of cultural literacy. In the modern introduction to Aubrey's Brief Lives ${ }^{25}$, as this collection has come to be known, we read:

"In Aubrey's day the false distinction had not yet been drawn between work, regarded as drudgery, and play, regarded as a good time, and educated men naturally sought their recreation in the study, rather than on the golf course. For in the seventeenth century learning was part of the joy of life, just as much as drinking or love-making, and it was just as often overdone."

This recreation in the study often took the form of mathematics. Aubrey lists soldiers, sailors, and clerics, amongst others, who became almost intoxicated with the study of mathematics, and in particular geometry. Perhaps the most prominent figure to become intoxicated in this way was the philosopher Thomas Hobbes. Aubrey writes:

"He [Hobbes] was 40 yeares old before he looked on Geometry; which happened accidentally. Being in a Gentleman's Library, Euclid's Elements lay open, and 'twas the 47 El.libri I [the Theorem of Pythagoras]. He read the proposition. By G--, sayed he (he would now and then sweare an emphati- 
call Oath by way of emphasis) this is impossible! So he reads the Demonstration of it, which referred him back to such a Proposition; which proposition he read. That referred him back to another, which he also read. Et sic deinceps [and so on] that at last he was demonstratively convinced of that trueth. This made him in love with Geometry."26

Now, as a word of warning to those of you rushing out to buy their copy of Euclid's Elements, it must be said that Hobbes' late flowering of geometrical insight and mathematical talent lead to some regrettable delusion of grandeur, including an ostensible solution to the problem of circle squaring, and a vicious dispute with Boyle and other more scientifically trained members of the Royal Society. ${ }^{27}$ Be that as it may, it remains as true today as it was then that a beautiful Euclidean proof can be an immense intellectual stimulus. 


\section{The $18^{\text {th }}$ Century and Beyond}

During the $18^{\text {th }}$ century, obvious cracks were beginning to form between the scientific and the humanistic culture. While the shifts in general cultural attitudes - the Zeitgeist if you like - are difficult to trace, there are two factors that played an obvious part in this development.

The first factor was the acceleration in mathematical and scientific research, which made it well-nigh impossible for the educated layman to keep abreast of the progress in these fields. The second factor was the increasing importance of applied mathematics and an emerging class of technocrats and engineers, which resulted in mathematics being seen and practised as a technical subject rather than as one of the liberal arts.

While in itself this does not have to be regarded as a malign development, it is rather more serious that some of the leading philosophers and literary figures of this time not only turned their backs on mathematics, but fundamentally questioned its suitability for helping us understand the world around us.

Johann Wolfgang von Goethe, whose $250^{\text {th }}$ anniversary we are celebrating this year, played a rather ambiguous rôle in this context, as might be expected from such an Olympian figure. By quoting the appropriate statement out of context, one can claim Goethe's support for many contradictory causes, as has been done for centuries. When it comes to mathematics, one can find evidence for the highest esteem on the grounds that mathematical achievements are beyond his powers; on the other hand, his comments on mathematicians are usually less than favourable, accusing them of a narrow and misguided worldview. The explanation for this lies in the ambivalent character assumed by mathematics in the $18^{\text {th }}$ century.

In ancient Greece, mathematics was not regarded as being capable of describing the ever changing nature. Even the inventions of Archimedes were essentially concerned with statics, and the motions of the planets as described by geometry were seen precisely as part of a realm where no secular changes occured. For mathematics as practised by the ancients, Goethe was full of admiration. But he was adamantly opposed to the epistemological claim of mathematics to be a source of knowledge about our world, and he outrightly refused the Kantian philosophy about the synthetic character of mathematics. In the mathematical sciences he saw spiritual degradation and a failure to grasp the fundamental phenomena of nature. Most famous is his venomous battle against Newton - who had been long dead at the time - over the nature of light, which ended in a resounding victory for Newton.

To make my views quite clear: There are many areas in the realm of human existence on which mathematics and the sciences have little or nothing to say. Even in areas where the mathematical viewpoint yields essential insight, 
it often does not provide a complete picture or the only way to look at certain phenomena. The success of the mathematical sciences has sometimes produced - in individual scientists - arrogance ${ }^{28}$ and a failure to see their limitations. But it is a dangerous step from this concession to the accusation of science as such as being arrogant, and to the attitude that took hold in the $18^{\text {th }}$ century and forms the basic supposition of many so-called postmodern thinkers, that the scientific enterprise, in particular in its reliance on mathematics, is fundamentally flawed.

Returning to Goethe, he is often quoted as saying that mathematicians are like the French: whatever you tell them, they translate into their own language, by which it becomes something completely different.

This likening of mathematicians to the French is perhaps not entirely accidental, for it was precisely the France of Goethe's time that not only produced some of the most fertile mathematical minds of the period, but also saw them actively engaged in the shaping of the post-revolutionary society. To name but the most significant ${ }^{29}$

- Gaspard Monge (1746 -1818), founder of the Ecole Polytechnique in 1794 and professor of geometry, minister of the marine in 1792, and member of Napoleon Bonaparte's expedition to Egypt.

- Lazare Carnot (1753-1823), Bonaparte's minister of war, who wrote important mathematical works even during his time in political office.

- Joseph Fourier (1768-1830), likewise member of Napoleon's expedition to Egypt and an influential diplomat there.

The list continues into the $19^{\text {th }}$ century with François Arago and Jean Victor Poncelet, and as late as the middle of our century we find the distinguished mathematicians Paul Painlevé and Emile Borel as minister of war and the marine, respectively. Admittedly, this list makes mathematicians appear to be a rather martial lot.

The men on this list are today remembered predominantly for their outstanding contributions to mathematics, however influential they may have been as politicians. In the United States, on the other hand, we find two Founding Fathers who also made important contributions to science. ${ }^{30}$ Everyone seems to know Benjamin Franklin (1706-1790) as the inventor of the lightning rod. But his scientific achievements go much deeper, and although they were more on the practical than the mathematical side of science, the story is too good not to be told.

Franklin's fundamental book Experiments and Observations on Electricity went through five editions in English and was translated into French, 
German, and Italian. It was read as much by the literate public, including clerics and aristocrats, as by scientists. Franklin was the first American to be elected as a foreign member of the Académie Française, and the only one for another century.

His scientific stature has been compared to Newton's in his day or Einstein's in ours. At any rate, his fame as a scholar played a significant rôle in securing French support for the American revolution. His popularity during a visit to Paris in 1776 was so great that medaillons and banners were printed with the motto Eripuit celeo fulmen sceptrumque tyrannis [he snatched lightning from the sky and the scepter from tyrants]. Louis XVI became so annoyed with Franklin being treated like a pop star that he presented his favourite mistress with a chamber pot containing a Franklin medaillon at the bottom. The other Founding Father with serious scientific interests was Thomas Jefferson (1743-1826), the third president of the United States. He mastered the geometry and calculus of Isaac Newton's Principia Mathematica and used it to calculate the optimal shape of a moldboard, the part of a plough that peels back and turns over the sod as the blade cuts through the soil. His design was not improved upon for over a century.

As late as 1876 the American politician James A. Garfield, later president of the United States, described how several delegates in the parliament of Ohio occupied themselves with mathematical problems during intervals - or long speeches, and he even published a new proof of the Theorem of Pythagoras. Try to imagine a modern-day politician doing the same.

As evidence for the growing incomprehension shown by humanist intellectuals towards scientific achievements - an issue that has of course been debated ever since C.P. Snow's famous Rede Lectures in 1959 on The Two Cultures $^{31}$ - one may observe in this context that a recent 250 page document describing the new history curriculum for high schools in the United States does not mention any scientific discovery or scientist, not even Benjamin Franklin. 


\section{Conclusion}

I hope I have amply demonstrated to you that mathematics has a central place in the history of ideas and fully deserves our appreciation. However, it is clearly not a new phenomenon that many people do not share this sense of appreciation. In 1935 the National Committee on the Teaching of Mathematics in the United States could still grandly declare that "much of [geometry's] importance lies in the fact that it is part of the common background and experience of educated men"32, but it was clear even then that the general educated public thought otherwise.

Nonetheless, in historical terms - as I have outlined - it is a relatively recent development that it has become socially acceptable even in educated circles to confess to complete mathematical ignorance. I believe that this matter should not be taken lightly.

It is too simple-minded to blame the schools for this state of affairs. After all, they only form a part of our intellectual socialisation. Much of this intellectual socialisation is due to the upbringing in the parental home and the general cultural climate of a society. Schools are obviously fighting a losing battle in a time where culture and public discourse have been swamped by the inanity dominating television, a time where education and art are expected to offer instant gratification instead of deep rewards acquired by hard labour.

There have been attempts at schools in this country and elsewhere to make mathematics more attractive by reducing the reliance on strict logical deduction and the amount of drill'33, and emphasizing the so-called 'real life' aspects of mathematics. This may superficially improve the performance in international educational surveys, but I am convinced that this approach perpetuates mathematical illiteracy.

Of course I do not object to attempts at making mathematics more attractive to the student; as an example, I have already pointed out how important it is to include cultural references. But this is just as much an appeal to other components of the school curriculum, such as history or art, which usually fail to mention mathematical and scientific achievements relevant to these fields.

The one thing however, that mathematics education can and has to offer to everybody is the training in rigorously deductive thinking. The intellectual discourse in our time would be of much higher quality if everybody who takes ideas seriously had gone through more than just a modicum of this training.

As Europeans we may still laugh at the State of Kansas for removing all references to the theory of evolution from its public schools curriculum, or at the majority whip of the US House of Representatives for regarding this 
theory as an intellectual poison that warps the mind and rots the soul ${ }^{34}$. But if we do not stay alert, such anti-intellectual debates will soon spread. I maintain that mathematics is an extremely useful antidote against such irrational tendencies.

The low student numbers in the exact sciences, not only in this country, should be a cause of concern for more than just the educators directly involved with these students. It is not only the livelihood of these educators which is at stake, but the sanity of a whole society. 


\section{Dankwoord}

Dames en heren, aan het einde gekomen van deze rede wil ik een aantal mensen bedanken.

Mijnheer de Rector Magnificus, leden van het College van Bestuur, leden van het Bestuur van de Faculteit der Wiskunde en Natuurwetenschappen. Ik dank $\mathrm{U}$ voor het door deze benoeming in mij gestelde vertrouwen. Met de benoeming van vier hoogleraren wiskunde in de afgelopen twee jaar heeft $\mathrm{U}$ het belang van de wiskunde duidelijk gemaakt, in een tijd waar veel mensen er anders over denken. In het bijzonder dank ik de leden van het Mathematisch Instituut die aan de totstandkoming van deze benoeming meegewerkt hebben. Ik beschouw het als een eer en voorrecht benoemd te zijn aan de oudste universiteit van Nederland.

I thank my mother and my late father for providing an environment that lived up to the Athenian demands I mentioned at the beginning of my lecture. Ours was not an academic home, but by their example they taught me intellectual honesty and curiosity.

My teachers at school probably knew that I wanted to be a mathematician long before I did, and when I stand here today it is also thanks to them. It was my physics teacher, Klaus Stegle, who suggested that I read Thomas Mann's Doktor Faustus, which was a better reading assignment than any other I have had at school.

I was fortunate to have several inspiring teachers at the universities of Göttingen, Cambridge, Zürich and Bonn who would deserve to be mentioned. Professor Erhard Heinz from the University of Göttingen might be very surprised to find himself singled out here, but it was actually thanks to his beautiful and rigorous analysis lectures that I gave up my misguided attempt at becoming a physicist.

My research supervisor Charles Thomas has always been a 'Doktorvater' in the most literal sense of the word, and I am happy that we have been continuing our collaboration over many years now. I am particularly pleased to see him here today with his wife Maria Thomas; together they have always made me feel very much at home in their family.

I thank my family and friends, who have come from as far as Moscow, Zürich, London, Staufen, Saarbrücken, Bochum, Göttingen and Leipzig to help make this a very special day for me.

My mathematical career has been shaped - and occasionally influenced behind the scenes - by Yasha Eliashberg, Jesús Gonzalo, Helmut Hofer, Dusa McDuff, and Edi Zehnder. I thank them all. 
Before we move over to the other side for the reception, it seems apt to quote a 19th century text on applied geometry ${ }^{35}$, aimed at the workers at Metz cathedral, and extolling the purifying influence of geometry on morals: "It is extremely rare to see a drunk geometer."

Ik heb gezegd. 


\section{Notes}

1. See [25], p. 75. Vitruvius wrote his Ten Books on Architecture around 30 B.C. I first learned Vitruvius' story about Aristippus from the beautiful book [9], which should be considered very seriously as a geometry text in schools. This and the book [8], in particular the article contained in the latter, 'Mathematics as the stepchild of contemporary culture' by N. Levitt, have also been a main source and inspiration for other parts of this lecture (the quotation at the end of the introduction is taken from that article). As a further source on issues discussed in this lecture see [26].

2. In his inaugural lecture in Tübingen [14], Konrad Knopp spoke of the cultural value of mathematics with considerably more pathos. While the style of that lecture may appear antiquated to the modern reader, this does not invalidate the views expressed there. I thank Frank Neumann for obtaining a copy of this lecture for me from the university library in Göttingen.

3. Pythagoras probably lived around 570-500 B.C.; see [2] for a summary of dates mentioned in various sources. The Pythagorean school was influential for centuries after the death of Pythagoras.

4. Euclid's Elements are easily available in many languages spoken on our planet today. The copy on my bookshelf is [5]. One of the standard English editions is [4], containing a useful commentary. For further historical and mathematical notes on the Elements see [9], [16].

5. cf. [18], pp. 203-204.

6. See [22], chapters 25 and 26, for more on the lasting influence of Euclid's Elements on philosophy and literature.

7. 'Tripos' is a name derived from the three-legged stool on which medieval undergraduates used to sit. In Cambridge it has come to denote a course of study.

8. A. Tacquet, Elementa geometriae planae et solidae, J. Mersius Antwerp, 1654; quoted after [9], p. 14. 
9. It makes me feel rather old to say that in 'my time' we still received a very good education in Euclidean geometry at school, but this can apparently no longer be taken for granted, see [12], cf. [3], [13]. See also the section on education in [8]. The attitude 'proofs are only for mathematicians', even at university, I regard as very saddening.

10. Not to be confused with cultural relativism, disguised as 'multicultural education', which I regard as extremely dangerous, cf. several of the excellent articles in [8].

11. I would have liked to present this proof during the lecture, but the timehonoured Academiegebouw does not provide modern audio-visual aids such as a blackboard. The proof and comments on its history can be found, for instance, in vol. 3 of [4], pp. 1 et seq., vol. 1 of [4], pp. 411414 , and [2], p. 170. One point that seems to be well established is that the discovery of the irrationality of $\sqrt{2}$ was made only after the death of Pythagoras.

12. cf. [17], in particular pp. 24-28, 57-61; for a discussion in the context of non-Euclidean geometry see [16], Section 34.3.

13. cf. [22], pp. 170-174.

14. [6], p. 547.

15. viz., the author of [20].

16. [15], quoted after the edition of 1997, pp. 571, 865-867.

17. [21], pp. 24, 38 .

18. cf., for instance, [9], pp. 71-72. Sadly enough, the 'proof' that the angle sum in a Euclidean triangle always equals 180 degrees by drawing a triangle and cutting out its angles - according to this source suggested by one of the most learned men of the time around 1025 A.D. - seems to be used again in some schools today.

19. See [11], in particular pp. 82-84, for a brief sketch of this history.

20. Although Otto von Simson was German, the German edition of his book [23] in my personal library is actually a translation of the American original. 
21. [23], p. 26, emphasis in the original. On the geometry of Gothic cathedrals see also [9].

22. [23], pp. 32-34.

23. [23], in particular pp. 38, 41-45, 220-221. The head of the school of Chartres, Thierry, owned a copy of the Elements in Latin translation.

24. [23], p. 56. Cf. also the intriguing study [10] on the use of cathedrals as solar observatories.

25. [1], p. xxxii.

26. [1], p. 150.

27. See [7], pp. 63-69, for a discussion of this dispute in the context of the recent postmodern attacks on science.

28. This arrogance has often been coupled with an air of exclusiveness towards women. But the 'feminist' thinkers who accuse the sciences of providing an exclusively male-oriented view are usually not convincing, often because they so obviously don't know what they are talking about, and do the women's cause more harm than good, cf. [8] and [7].

29. cf. [20].

30. cf. D.R. Herschbach, 'Imagining gardens with real toads', in [8], pp. 11-30

31. [24].

32. quoted after [9], p. 17.

33. On this issue and the relevance of evolutionary psychology cf. the discussion in [19], pp. 338-342.

34. This information is taken from the article 'Throwing away a part of our universe' by C. Willis, Financial Times, 11 September 1999.

35. C.L. Bergery, Géométrie appliqué à l'industrie, à l'usage des artistes et les ouvriers, Thiel, Metz, 1828; quoted after [9], p. 21. 


\section{References}

[1] J. Aubrey, Aubrey's Brief Lives, edited by O.L. Dick, Nonpareil Books, Jaffrey, New Hampshire, 1996.

[2] M. Cantor, Vorlesungen über Geschichte der Mathematik, Erster Band, Teubner Verlag, 1894.

[3] D. van Delft, 'Pannenkoekwiskunde', NRC Handelsblad, 25 April 1998, p. 53.

[4] Euclid, The Elements (With Introduction and Commentary by Sir Thomas L. Heath), 3 volumes, Dover Publications, New York, 1956.

[5] Euklid, Die Elemente, Wissenschaftliche Buchgesellschaft, Darmstadt, 1980.

[6] J.W. Goethe, Faust (A. Schöne, ed.), Goethe-Ausgabe Band 7/1, Deutscher Klassiker Verlag, Frankfurt am Main, 1999.

[7] P.R. Gross and N. Levitt, Higher Superstition - The Academic Left and its Quarrels with Science, The Johns Hopkins University Press, Baltimore, 1994.

[8] P.R. Gross, N. Levitt, and M.W. Lewis (eds.), The Flight from Science and Reason, The New York Academy of Sciences, New York, 1996.

[9] J.L. Heilbron, Geometry Civilized: History, Culture, and Technique, Clarendon Press, Oxford, 1998.

[10] J.L. Heilbron, The Sun in the Church: Cathedrals as Solar Observatories, Harvard University Press, Cambridge, MA, 1999.

[11] P. Kalchthaler, Freiburger Wege - Strassennamen mit Geschichte, Band 1, Rombach Verlag, Freiburg im Breisgau, 1998.

[12] F. Keune, Naar de knoppen, Inaugurale rede, Katholieke Universiteit Nijmegen, 21 April 1998.

[13] F. Keune, Ingezonden brief naar NRC Handelsblad, 29 April 1998. 
[14] K. Knopp, Mathematik und Kultur, Preussische Jahrbücher 211 (1928), 283-300.

[15] Th. Mann, Der Zauberberg, S. Fischer Verlag, Berlin, 1924.

[16] G.E. Martin, The Foundations of Geometry and the Non-Euclidean Plane, Springer Verlag, New York, 1975.

[17] K. Meyberg, Algebra, Teil 2, Carl Hanser Verlag, München, 1976.

[18] O. Neugebauer, Vorlesungen über Geschichte der antiken Wissenschaften. Erster Band: Vorgriechische Mathematik, Springer Verlag, Berlin, 1934.

[19] S. Pinker, How the Mind Works, Penguin Books, London, 1998.

[20] A. Pringsheim, Über Wert und angeblichen Unwert der Mathematik, Jahresbericht der Deutschen Mathematiker-Vereinigung 13 (1904), 357-382.

[21] Proclus, A Commentary on the First Book of Euclid's Elements, Princeton University Press, Princeton, 1992.

[22] K. Radbruch, Mathematische Spuren in der Literatur, Wissenschaftliche Buchgesellschaft, Darmstadt, 1997.

[23] O. von Simson, Die gotische Kathedrale, Wissenschaftliche Buchgesellschaft, Darmstadt, 1992.

[24] C.P. Snow, The Two Cultures, Cambridge University Press, Canto edition, 1993.

[25] Vitruvius, Ten Books on Architecture (ed. by I.D. Rowland and T.N. Howe), Cambridge University Press, Cambridge, 1999.

[26] A.M. White (ed.), Essays in Humanistic Mathematics, The Mathematical Association of America, Washington, 1993. 
